\title{
Mechanism of Inhibition of Immunoglobulin G-mediated Phagocytosis by Monoclonal Antibodies That Recognize the Mac-1 Antigen
}

\author{
Eric J. Brown, John F. Bohnsack, and Hattie D. Gresham
}

Departments of Medicine, and Microbiology and Immunology, Washington University School of Medicine, St. Louis, Missouri 63110

\begin{abstract}
We have investigated the effects of the monoclonal antibodies against the cell surface molecule Mac-1 on C3bi-mediated rosetting and IgG-mediated rosetting and phagocytosis by human peripheral blood monocytes. Highly purified M1/70 $F\left(a b^{\prime}\right)_{2}$, used in the fluid phase, inhibited both monocyte functions. Half-maximal $\mathrm{C} 3 \mathrm{bi}$ rosette inhibition occurred at a concentration of $2 \mathrm{nM} \mathrm{F}\left(\mathrm{ab}^{\prime}\right)_{2} \mathrm{M1} / 70$. An equivalent decrease in IgG-mediated rosetting required $10 \mathrm{nM} \mathrm{M1} / 70 \mathrm{~F}\left(\mathrm{ab}^{\prime}\right)_{2}$, and $50 \%$ inhibition of IgG-mediated phagocytosis required $7 \mathrm{nM}$ antibody. Mo-1 F(ab') 2 inhibited EC3bi binding with an ID Do $_{50}$ $0.3 \mathrm{nM}$, whereas $50 \%$ decrease in IgG-mediated rosetting required $70 \mathrm{nM}$ of this antibody. OKM1 did not inhibit rosettes of sheep erythrocytes opsonized with IgG antibody (EA) at all. $\mathrm{F}\left(\mathbf{a b}^{\prime}\right)_{2} \mathrm{M1} / 70$ did not affect the binding of monomeric human IgG to monocytes, but did substantially decrease the binding of IgG aggregates. Half-maximal inhibition of aggregated IgG binding at $0^{\circ} \mathrm{C}$ occurred at $8 \mathrm{nM} \mathrm{F}\left(\mathrm{ab}^{\prime}\right)_{2} \mathrm{M1} / 70$, very close to the concentration that caused equivalent inhibition of IgG-mediated phagocytosis. Aggregated IgG inhibited the binding of radiolabeled M1/70 to monocytes by $\sim 40 \%$, suggesting that some, but not all Mac-1 molecules were associated with IgG receptors under these conditions.
\end{abstract}

When cells were allowed to adhere to surfaces coated with M1/70 or Mo-1 $\mathrm{F}\left(\mathrm{ab}^{\prime}\right)_{2}$, C3bi-mediated rosetting was inhibited, but IgG mediated-phagocytosis was unaffected. Moreover, the dose response of inhibition of phagocytosis by fluidphase $F\left(a^{\prime}\right)_{2}$, of anti-Mac-1 monoclonals was similar on monocytes adherent to albumin-coated and antibody-coated surfaces. Kinetic experiments showed that even prolonged incubation of monocytes on M1/70 coated surfaces did not lead to inhibition of EA binding nor did these incubations alter the dose response for inhibition of EA binding by fluid-phase M1/70 $\mathrm{F}\left(\mathrm{ab}^{\prime}\right)_{2}$. This suggested that not all molecules recognized by $\mathrm{M1} / 70$ are freely mobile in the plasma membrane. Indeed, only $\sim 60 \%$ of ${ }^{125} \mathrm{I}-\mathrm{M1} / 70$-biding sites were lost even after $4 \mathrm{~h}$ when monocytes were adherent to M1/70-coated surfaces. We conclude that some anti-Mac-1 antibodies can inhibit EA binding because of their epitope specificity, independent of any direct interaction with monocyte Fc receptors. This interference with IgG-Fc receptor-mediated binding and inges-

Dr. Bohnsack's current address is Department of Immunology, Scripps Clinic and Research Foundation, La Jolla, CA 92037. Address reprint requests to Dr. Brown, Campus Box 8051, Washington University School of Medicine, 660 South Euclid Avenue, St. Louis, MO 63110.

Received for publication 23 October 1986 and in revised form 11 May 1987.

J. Clin. Invest.

(C) The American Society for Clinical Investigation, Inc.

$0021-9738 / 88 / 02 / 0365 / 11 \$ 2.00$

Volume 81, February 1988, 365-375 tion apparently occurs because of antibody binding to a subpopulation of Mac-1 molecules which are associated with IgG Fc receptors and remain on the apical membrane of monocytes adherent to anti-Mac-1-coated surfaces. We suggest that there may be two functionally distinct molecules on human monocytes recognized by M1/70 and Mo-1 that can be distinguished by their mobility in the plane of the monocyte membrane. The more mobile form of Mac-1 is involved in C3bi rosettes, and does not affect IgG-mediated phagocytosis. The other antigen recognized by $M 1 / 70$ does not diffuse within the plane of the membrane; ligation of the latter molecule by antibody is associated with inhibition of IgG-mediated phagocytosis.

\section{Introduction}

The mAb M1/70 recognizes a two-chain, cell surface glycoprotein on mouse and human leukocytes termed Mac-1 $(1,2)$. This antigen is a member of a family of cell surface molecules which are heterodimers of noncovalently linked polypeptides. Although each member of the family has a unique $\alpha$ chain, the $\beta$ chains of all these molecules are apparently identical. The Mac-1 antigen is expressed on granulocytes, monocytes, natural killer cells, and some B and T lymphocytes and has been functionally identified with the type 3 complement receptor $(\mathrm{CR} 3)^{1}$ and the $\mathrm{iC} 3 \mathrm{~b}$ receptor (3). M1/70 and certain other antibodies that recognize Mac- 1 inhibit the binding of $\mathrm{iC} 3 \mathrm{~b}-$ coated erythrocytes (EC3bi) to leukocytes. Moreover, cells from patients lacking this membrane antigen fail to rosette with EC3bi.

Some studies have attributed other inhibitory properties to monoclonal antibodies against Mac-1. Arnaout et al. (4) showed that the IgG2a mAb Mo-1 (which recognizes Mac-1) and its Fab fragment inhibited IgG-Fc receptor-mediated phagocytosis as well as EC3bi rosetting (4). We have shown that M1/70 inhibited the binding of fibronectin-coated microspheres to monocytes and PMN (5), and Ezekowitz et al. (6) have shown that Mo-1 and M1/70 inhibited zymosan binding to monocytes and macrophages. Similar inhibition of zymosan phagocytosis has been found by Ross et al. (7), who showed that some anti-Mac-1 mAb also could inhibit the ingestion of unopsonized rabbit erythrocytes. These studies suggest that Mac-1 plays an important role in the general adhesive properties of leukocytes, since it is unlikely that each of these inhibitory properties of the anti-Mac-1 antibodies can be ascribed to disruption of a single receptor-ligand interaction. This hypothesis is supported by studies in patients deficient in Mac-1. These patients' cells exhibit impaired chemotaxis, aggregation, and substrate adherence in addition to their inability to rosette with iC3b-coated particles.

1. Abbreviations used in this paper: $\mathrm{AI}$, attachment index; CR3, complement receptor 3; EA, erythrocytes (sheep) opsonized with IgG antibody; EC3bi, erythrocytes (sheep) opsonized with iC3b receptor; PI, phagocytotic index. 
In this study we have examined the mechanism by which anti-Mac-1 antibodies interfere with cellular functions not obviously dependent on soluble ligand interactions with the Mac-1 molecule. We have studied the inhibition of IgG-mediated rosetting and phagocytosis by M1/70 and Mo-1 in detail. We have shown that both Mo-1 and $\mathrm{M} 1 / 70 \mathrm{~F}\left(\mathrm{ab}^{\prime}\right)_{2}$, which do not interact at all with monocyte Fc receptors, inhibit IgGmediated erythrocyte binding and phagocytosis. Binding studies with monomeric and multimeric IgG showed that M1/70 inhibited multimeric IgG binding while having no effect on monomeric IgG binding to the Fc receptor. Aggregated IgG was able to inhibit the binding of ${ }^{125} \mathrm{I}-\mathrm{M} 1 / 70$ to monocytes by almost $40 \%$, while it had no effect on the binding of monoclonal anti-CR1. This suggested that some, but not all Mac-1 molecules were associated with IgG Fc receptors. By adhering $\mathrm{M} 1 / 70 \mathrm{~F}\left(\mathrm{ab}^{\prime}\right)_{2}$ to surfaces, we have been able to distinguish Mac-1 molecules involved in C3bi rosetting from those involved in IgG-mediated phagocytosis. Adherent $\mathrm{M} 1 / 70 \mathrm{~F}\left(\mathrm{ab}^{\prime}\right)_{2}$ modulated CR3 function, as previously reported (3). However, this modulation of Mac-1 to the adherent surface of the monocytes did not affect either IgG receptor-mediated phagocytosis or the continued potent inhibitory effect of fluid-phase M1/70 $\mathrm{F}\left(\mathrm{ab}^{\prime}\right)_{2}$ on this process. Under these conditions, $40 \%$ of cell surface Mac-1 antigen remained on the apical membrane of monocytes plated onto $\mathrm{M} 1 / 70$ bearing surfaces, despite the loss of $75-90 \%$ of the cells' ability to bind EC 3 bi. We suggest that there are diffusable and nondiffusable forms of the antigen recognized by $M 1 / 70$ in the monocyte membrane. The diffusing molecule is associated primarily with CR3 function; ligation of the nondiffusing form by $\mathrm{M} 1 / 70$ is associated with inhibition of $\mathrm{IgG} F c$ receptor function.

\section{Methods}

\section{Monoclonal antibodies}

The cell line producing M1/70 was obtained from the American Type Culture Collection, Rockville, MD (ATCC No. TIB 128). The cells were grown in Dulbecco's minimal essential medium (DME) supplemented with $15 \%$ fetal calf serum, $4 \mathrm{mM}$ glutamine, $20 \mathrm{mM}$ Hepes, penicillin, gentamicin, and amphotericin. Conditioned medium was harvested, and the rat IgG2b purified by a modification of the method of Ault and Springer (1). After DEAE-Sephacel chromatography as described, three distinct antibody containing peaks were found, with the majority of the M1/70 eluting at $0.2 \mathrm{M} \mathrm{NaCl}$. This peak was pooled, concentrated, and applied to a 500-ml Biogel A0.5m column (Bio-Rad Laboratories, Richmond, CA). The antibody peak was again pooled and concentrated and then digested for $24 \mathrm{~h}$ with pepsin as described (8). The pepsin digest was reapplied to the Biogel $\mathrm{A} 0.5 \mathrm{~m}$ column, and the column fractions were assayed for the presence of $F\left(a b^{\prime}\right)_{2}$ and intact IgG by SDS-PAGE (9). Fractions containing $F\left(a b^{\prime}\right)_{2}$ but little intact IgG were pooled and applied to a 600-ml Sephadex G150 Superfine column (Pharmacia Fine Chemicals, Piscataway, NJ). The column was again assayed by SDS-PAGE, and fractions which contained $F\left(a b^{\prime}\right)_{2}$ but no visible intact IgG by silver staining were pooled. This pool was assayed by SDS-PAGE and found to contain no intact IgG (Fig. 1). Moreover, on a Western blot (10) capable of detecting $4.5 \mathrm{ng}$ of IgG, no intact IgG was seen on electrophoresis and transfer of $1.5 \mu \mathrm{g}$ of the $\mathrm{F}\left(\mathrm{ab}^{\prime}\right)_{2}$ pool. Thus, the $\mathrm{F}\left(\mathrm{ab}^{\prime}\right)_{2} \mathrm{M} 1 / 70$ contained $<0.3 \%$ intact IgG. Mo-1 (11) ascites was the kind gift of Dr. R. F. Todd III, University of Michigan School of Medicine. IgG Mo-1 was purified by sequential octanoic acid (12) and protein A-Sepharose purification. $\mathrm{F}\left(\mathrm{ab}^{\prime}\right)_{2}$ were prepared as described (13); residual IgG was removed with protein A-Sepharose, and pepsin and Fc fragments were removed by

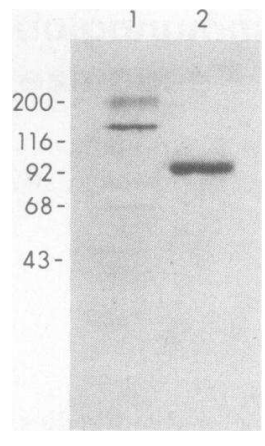

Figure 1. $\mathrm{F}\left(\mathrm{ab}^{\prime}\right)_{2} \mathrm{M} 1 / 70$. Lane 1 , IgG M1/70 after Biogel A0.5M chromatography with intact IgG and one major contaminant. Lane 2, the final preparation of $F\left(a b^{\prime}\right)_{2} M 1 / 70$, containing no visible intact IgG. Proteins were electrophoresed on 5-15\% gradient SDS-PAGE under nonreducing conditions.

chromatography on Ultragel ACA 54 (Spectrum Medical, Los Angeles, CA). Mo-1 $\mathrm{F}\left(\mathrm{ab}^{\prime}\right)_{2}$ showed a single band on SDS-PAGE.

IgG of the monoclonal anti-CR1 3D9 was purified as described (14). OKM1 was purchased from Ortho Diagnostics, Raritan, NJ.

\section{Cells}

Monocytes were obtained from the buffy coats from whole units of blood by centrifugation on cushions of Ficoll-Hypaque followed by counter current elutriation as described (15). 85-95\% of cells in all preparations of monocytes stained with nonspecific esterase. In all experiments, cells were used on the day of purification. Monocytes were washed three times in RPMI-1640 containing antibiotics, but without serum, before use in experiments.

Phagocytic targets. Sheep erythrocytes (E) were obtained, washed and sensitized as previously described (16). Except where indicated, E were opsonized with a 1:500 dilution of rabbit anti-E IgG (EA). EC3bi were prepared as previously described (16) from E sensitized with rabbit IgM, guinea pig $\mathrm{Cl}$, and the human complement components $\mathrm{C} 4, \mathrm{C} 2$, and $25 \mathrm{U}$ of $\mathrm{C} 3$, prior to incubation with EDTA and factors $\mathrm{H}$ and $\mathrm{I}$. The EA bore 10,000 molecules of $\mathrm{IgG} / \mathrm{E}$ and the EC $3 \mathrm{bi}$ bore $\sim 20,000$ molecules of C3/E.

Protein coating of phagocytosis chambers. In some experiments, monocytes were incubated in Labtek chambers (Miles Scientific, Naperville, IL.), which had been precoated with various proteins. For coating with $\mathrm{M} 1 / 70 \mathrm{~F}\left(\mathrm{ab}^{\prime}\right)_{2}$ or albumin, Labtek slides were washed and coated with poly-L-lysine (Sigma Chemical Co., St. Louis, MO) exactly as previously described for glass coverslips (17). Thereafter, poly-L-lysine-coated chambers were incubated with glutaraldehyde, and then with various concentrations of $\mathrm{M} 1 / 70 \mathrm{~F}\left(\mathrm{ab}^{\prime}\right)_{2}$ or with $50 \mu \mathrm{g} / \mathrm{ml}$ bovine serum albumin (BSA) as a control. After $1 \mathrm{~h}$ at room temperature, wells were washed, and residual glutaraldehyde activated sites were quenched by incubation with $0.1 \mathrm{M}$ glycine, $1 \% \mathrm{BSA}, \mathrm{pH}$ 7.5.

Phagocytosis and adherence assays. Phagocytosis and adherence assays were performed by a minor modification of a previously described method (11). Briefly, $1.5 \times 10^{5}$ monocytes were allowed to adhere to protein coated or uncoated Labtek chambers for $30 \mathrm{~min}$ at $37^{\circ} \mathrm{C}$. Fluid phase anti-Mac- $1 \mathrm{~F}\left(\mathrm{ab}^{\prime}\right)_{2}$, control antibody, or buffer was added to the cells for $15 \mathrm{~min}$. To prevent interaction of EC3bi with CR1 (18) during EC3bi adherence assays, $10 \mu \mathrm{g} / \mathrm{ml}$ of monoclonal 3D9, an antibody that recognizes CR1 and inhibits CR1-mediated rosettes (19), was included at this step. This assured that EC3bi were binding only to CR3. Anti-CR1 was not routinely included in EA phagocytosis assays; 3D9 is known to have no effect on EA phagocytosis (14). Next, $1 \times 10^{7} \mathrm{EA}$ or EC3bi were added and centrifuged onto the monocyte monolayer at $50 \mathrm{~g}$. After $30 \mathrm{~min}$ more at $37^{\circ} \mathrm{C}$, adherence or phagocytosis was quantitated as previously described (15). The number of $\mathrm{E}$ bound to 100 monocytes is the attachment index (AI); the number of $E$ ingested by 100 monocytes is the phagocytic index (PI).

IgG binding studies. Quantitation of IgG Fc receptors on monocytes incubated in the presence or absence of $\mathrm{M} 1 / 70 \mathrm{~F}\left(\mathrm{ab}^{\prime}\right)_{2}$ was performed as described (20). Briefly, $1 \times 10^{6}$ monocytes were incubated with $10 \mu \mathrm{g} / \mathrm{ml} \mathrm{M} 1 / 70 \mathrm{~F}\left(\mathrm{ab}^{\prime}\right)_{2}$ or buffer in $150 \mu \mathrm{l}$ of total volume at $37^{\circ} \mathrm{C}$ for $15 \mathrm{~min}$. Various concentrations of monomeric ${ }^{125} \mathrm{I}-\mathrm{IgG}$ were then added to the cells with or without $30 \mu \mathrm{g}$ of unlabeled monomeric 
IgG, a concentration previously determined to saturate Fc binding. Cells were incubated for a further $45 \mathrm{~min}$ at $37^{\circ} \mathrm{C}$, removed from incubation, and centrifuged at $12,000 \mathrm{~g}$ through Versilube F-50 (General Electric Co., Waterford, NY). ${ }^{125}$ I associated with the monocyte pellet was quantitated by aspirating the supernatant, cutting the tubes, and counting the cell pellet.

In some experiments aggregated IgG was used to assess IgG Fc receptor function. IgG was aggregated and aggregates separated from monomeric IgG as described (21), using an additional Biogel A5M (Bio-Rad Laboratories) chromatography step to separate aggregated from monomeric IgG. Human IgG at $5-10 \mathrm{mg} / \mathrm{ml}$ was incubated at $63^{\circ} \mathrm{C}$ for $15 \mathrm{~min}$. The IgG was centrifuged at $100,000 \mathrm{~g}$ for $60 \mathrm{~min}$, and the bottom half of the centrifuged tube, excluding the insoluble pellet, was applied to a 500-ml Biogel A5m column. Protein that chromatographed in the void volume of the column $\left(>1.8 \times 10^{6} \mathrm{D}\right)$ was used as aggregated IgG. Aliquots of this material were radiolabeled or fluoresceinated as described (22). In cell binding experiments, $1 \times 10^{6}$ monocytes were incubated with various concentrations of $\mathrm{M} 1 / 70 \mathrm{~F}\left(\mathrm{ab}^{\prime}\right)_{2}$ or with buffer at $0^{\circ} \mathrm{C}$ in a melting ice bath. Then various concentrations of fluoresceinated aggregated IgG were incubated with cells, with or without $10 \mu \mathrm{g}$ of unlabeled aggregate. After a 30-min incubation at $0^{\circ} \mathrm{C}$, cells were washed twice with ice-cold buffer, and fixed with paraformaldehyde as described (15). Fixed cells were analyzed by fluorescent flow microcytometry using a linear fluorescence scale, and specific fluorescence was considered the difference between the mean fluorescent channel of cells incubated with and without unfluoresceinated IgG. In experiments that analyzed binding of ${ }^{125} \mathrm{I}$-aggregated IgG to cells at $37^{\circ} \mathrm{C}$, all incubations were performed at $37^{\circ} \mathrm{C}$ rather than $0^{\circ} \mathrm{C}$. Bound and free radiolabel was separated by centrifuging the cells through Versilube F-50 at $15,000 \mathrm{~g}$ for $5 \mathrm{~min}$. Supernatant was aspirated, and cell pellet-associated radioactivity was ascertained.

\section{Binding of ${ }^{125} \mathrm{I}-\mathrm{MI} / 70$}

For fluid-phase assays of ${ }^{125} \mathrm{I}-\mathrm{M} 1 / 70$ binding, $1 \times 10^{6}$ monocytes were suspended in HBSS $^{=}$containing $1 \%$ BSA with or without various potential inhibitors of $\mathrm{M} 1 / 70$ binding for $30 \mathrm{~min}$ at $4^{\circ} \mathrm{C}$. After this preincubation, sufficient ${ }^{125} \mathrm{I}-\mathrm{M} 1 / 70$ was added to give a final concentration of $2 \mu \mathrm{g} / \mathrm{ml}$, and the incubation was continued for $1 \mathrm{hr}$ further at $4^{\circ} \mathrm{C}$. Cell bound was separated from unbound ${ }^{125} \mathrm{I}$ by centrifugation through Versilube F-50. The binding of ${ }^{125} \mathrm{I}-\mathrm{M} 1 / 70$ in the presence of $200 \mu \mathrm{g} / \mathrm{ml}$ unlabeled M1/70 was considered to be nonspecific binding and was subtracted from all values before determination of the number of bound antibody molecules. The binding of ${ }^{125} \mathrm{I}-3 \mathrm{D} 9$ to monocytes CR1 was determined in an identical manner. For both M1/70 and 3D9, nonspecific binding represented $<10 \%$ of total ${ }^{125}$ I bound.

In some experiments the binding of ${ }^{125} \mathrm{I}-\mathrm{M} 1 / 70$ to cells adherent to surfaces coated with $5 \mu \mathrm{g}$ of M1/70 was compared to cells adherent to surfaces coated with $5 \mu \mathrm{g}$ of 3D9 anti-CR 1 as a control. One million monocytes were allowed to adhere to the coated surfaces for $2-4 \mathrm{~h}$ at $37^{\circ} \mathrm{C}$ in a humidified environment containing $5 \% \mathrm{CO}_{2}$. After this incubation, supernatant fluid was aspirated and replaced with ice-cold PBS containing $2 \%$ bovine serum albumin and $3 \mu \mathrm{g} / \mathrm{ml}^{125} \mathrm{I}-\mathrm{Ml} / 70$. Bound radiolabel was quantitated after a $1-\mathrm{h}$ incubation at $4^{\circ} \mathrm{C}$ by extensive washing of the plate-adherent cells with cold PBS, followed by cell solubilization with $1 \mathrm{ml}$ of $0.1 \mathrm{M} \mathrm{NaOH}$ containing $1 \%$ SDS. Nonspecific binding was determined by inclusion of $100 \mu \mathrm{g} / \mathrm{ml}$ unlabeled M1/70 along with ${ }^{125} \mathrm{I}-\mathrm{M} 1 / 70$ in some wells. All values are reported as the specific ${ }^{125} \mathrm{I}-\mathrm{M} 1 / 70$ bound and represent the mean of two to five experiments performed in duplicate.

\section{Results}

Anti-Mac-1 M1/70 F(ab') ${ }_{2}$ inhibit EA rosetting and phagocytosis. Several anti-Mac-1 antibodies inhibit EC3bi rosettes with human myeloid cells $(3,4,23,24)$. Some of these antibodies also inhibit IgG-mediated phagocytosis by monocytes and PMN $(4,24)$. We have confirmed that $\mathrm{M} 1 / 70 \mathrm{~F}\left(\mathrm{ab}^{\prime}\right)_{2}$ and
Mo-1 $\mathrm{F}\left(\mathrm{ab}^{\prime}\right)_{2}$ have both these properties, inhibiting both EC3bi rosettes and EA phagocytosis (Figs. 2 and 3). Inhibition of C3bi rosettes occurred at somewhat lower concentrations of M1/70 than equivalent inhibition of phagocytosis. 50\% inhibition of EC3bi rosettes occurred at a concentration of $0.2 \mu \mathrm{g} / \mathrm{ml}$ $\mathrm{F}\left(\mathrm{ab}^{\prime}\right)_{2}(2 \mathrm{nM})$, whereas equivalent inhibition of EA phagocytosis required $0.7 \mu \mathrm{g} / \mathrm{ml}(7 \mathrm{nM}) \mathrm{Ml} / 70$ (Fig. 2). $\mathrm{Ml} / 70 \mathrm{~F}\left(\mathrm{ab}^{\prime}\right)_{2}$ inhibited EA rosettes as well as phagocytosis, with half-maximal inhibition at $10 \mathrm{nM}$. The inhibition of EA binding was not due to nonspecific blocking of the $F c$ receptor since the $F\left(a b^{\prime}\right)_{2}$ preparation contained $<0.003 \mu \mathrm{g} / \mathrm{ml}$ of intact $\mathrm{IgG}$ at this concentration. Mo-1 $\mathrm{F}\left(\mathrm{ab}^{\prime}\right)_{2}$ inhibited EC3bi rosettes at lower concentrations than $\mathrm{M} 1 / 70$, since half-maximal rosette inhibition occurred at $0.3 \mathrm{nM}$ (Fig. 3). In contrast, much more Mo-1 than M1/70 was required to inhibit EA rosettes, with $50 \%$ inhibition requiring $\sim 70 \mathrm{nM}$ Mo-1. Inhibition of EA phagocytosis also occurred with Mo-1 (Fab') ${ }_{2}$, and half-maximal inhibition required $100 \mathrm{nM} \mathrm{F}\left(\mathrm{ab}^{\prime}\right)_{2}$. Intact IgG Mo-1 inhibited EA rosettes with an $\mathrm{ID}_{50}$ of $0.3 \mathrm{nM}$, equivalent to its effect on EC3bi rosettes. This results from IgG Fc binding to the highaffinity IgG receptor on monocytes (25). The effect of Mo-1 $\mathrm{F}(\mathrm{ab})_{2}$ on EA binding and phagocytosis did not result from residual intact IgG in the $F\left(a^{\prime}\right)_{2}$ because no residual intact IgG was detectable on Western blots. Moreover, there was no effect of solid-phase Mo-1 $\mathrm{F}\left(\mathrm{ab}^{\prime}\right)_{2}$ on EA rosettes (see below) whereas as little as $0.05 \mu \mathrm{g} / \mathrm{ml}$ intact IgG Mo-1 attached to a solid phase completely inhibited EA rosettes. $\mathrm{F}\left(\mathrm{ab}^{\prime}\right)_{2} 3 \mathrm{D} 9$, a monoclonal antibody to CR1, and whole IgG OKM1, another antibody that recognizes Mac-1 but does not inhibit EC3bi rosettes (3), did not affect EA phagocytosis when used in the fluid phase. The inhibition of EA rosettes and phagocytosis by M1/70 could not be overcome by increasing the amount of IgG used to sensitize the $E$ to a maximal subagglutinating dose (Fig. 4). From these data we concluded that M1/70 and Mo-1 inhibit both EC3bi rosettes and EA rosetting and phagocytosis, but with different dose responses. While M1/70 was almost as effective at inhibiting the IgG receptor function as CR3, Mo-1 was much more effective for inhibition of CR3. This, along with the failure of OKM1 to inhibit IgG receptor function,

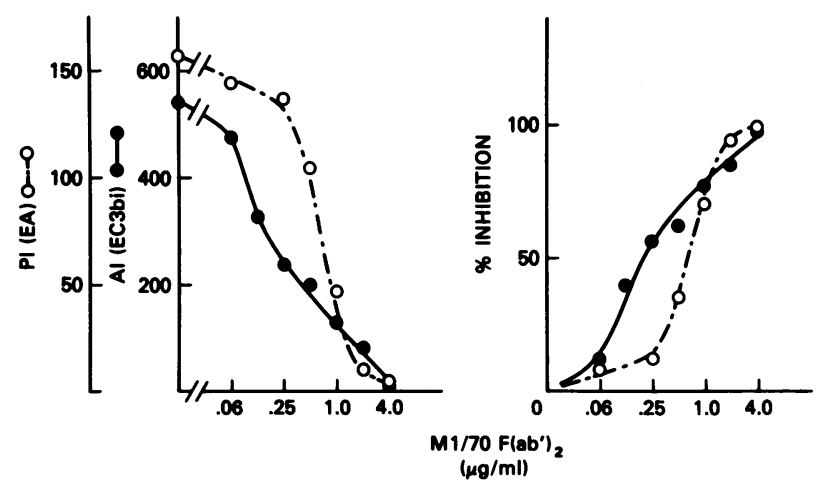

Figure 2. Inhibition of EC3bi rosettes and EA phagocytosis by fluidphase $\mathrm{M} 1 / 70 \mathrm{~F}\left(\mathrm{ab}^{\prime}\right)_{2}$. The dose responses of inhibition of EC3bi rosettes $(\bullet)$ and EA phagocytosis ( $(0)$ by fluid-phase $\mathrm{M} 1 / 70 \mathrm{~F}\left(\mathrm{ab}^{\prime}\right)_{2}$ are compared. (Left panel) Data are presented as attachment index (AI) and phagocytic index (PI). (Right panel) Data are presented as percent inhibition of rosetting or phagocytosis compared with the absence of $\mathrm{M} 1 / 70$. The $\mathrm{ID}_{50}$ of $\mathrm{M} 1 / 70 \mathrm{~F}\left(\mathrm{ab}^{\prime}\right)_{2}$ for EC3bi rosetting is 2 $\mathrm{nM}$ and for EA phagocytosis is $7 \mathrm{nM}$. 


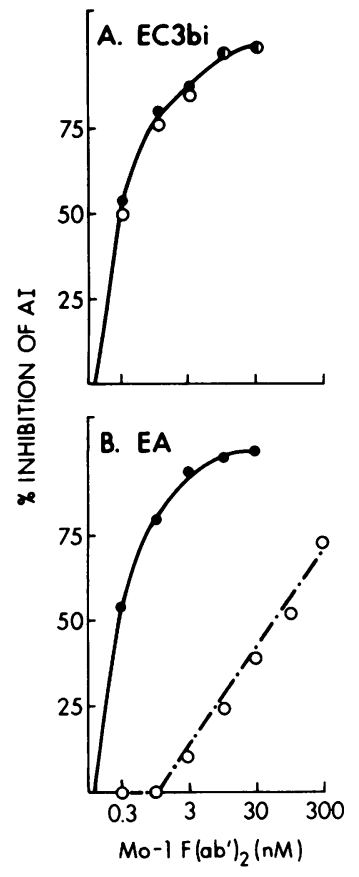

Figure 3. Inhibition of EC3bi rosettes and EA phagocytosis by fluid-phase Mo-1. The inhibitory effects of Mo-1 $\operatorname{IgG}(\bullet)$ and Mo-1 $\mathrm{F}\left(\mathrm{ab}^{\prime}\right)_{2}(\mathrm{O})$ on $(A)$ EC3bi attachment and $(B)$ EA attachment are compared. The ID $_{50}$ for EC3bi attachment was $0.3 \mathrm{nM}$, similar for intact IgG and $F\left(a b^{\prime}\right)_{2}$. In contrast Mo-1 $\mathrm{F}\left(\mathrm{ab}^{\prime}\right)_{2}$ were very much less efficient at inhibition of EA attachment, with an $\mathrm{ED}_{50}$ of $70 \mathrm{nM}$.

suggests that inhibition of EA binding and phagocytosis by anti-Mac-1 antibodies is epitope specific.

$M 1 / 70 F\left(a b^{\prime}\right)_{2}$ inhibits the binding of aggregated IgG but not monomeric IgG to monocytes. Because $\mathrm{M1} / 70$ was more effective than Mo-1 for inhibition of IgG Fc receptor rosetting and phagocytosis, we examined its mechanism of inhibition in detail. The abrogation of EC3bi rosettes by M1/70 and Mo- 1 is thought to be due to an inhibition of the direct binding of the ligand C3bi, to the $\alpha$ chain of Mac-1 (26). However, there is no evidence that Mac-1 acts as an IgG receptor. Instead, there are two other IgG receptors on monocytes (27). We investigated the possibility that $\mathrm{M} 1 / 70 \mathrm{~F}\left(\mathrm{ab}^{\prime}\right)_{2}$ inhibited IgG binding to monocyte Fc receptors. Monomeric human IgG binds to a $72-k D$ high affinity receptor on monocytes $(20,28)$. The binding of monomeric ${ }^{125} \mathrm{I}-\mathrm{IgG}$ was assessed in buffer and in the presence of $100 \mathrm{nM} \mathrm{M1/70} \mathrm{F}\left(\mathrm{ab}^{\prime}\right)_{2}(\sim 15$ times as much as required for $50 \%$ inhibition of EA phagocytosis). A representative binding curve is shown in Fig. 5. Rather than a decrease, the number of IgG binding sites was slightly increased in the presence of $\mathrm{M} 1 / 70 \mathrm{~F}\left(\mathrm{ab}^{\prime}\right)_{2}$. This was true in each of three experiments with monocytes from different individuals, although the increase in receptor number did not reach statistical significance $(38,000 \pm 4,000$ (SD) in the presence of $\mathrm{M} 1 / 70$

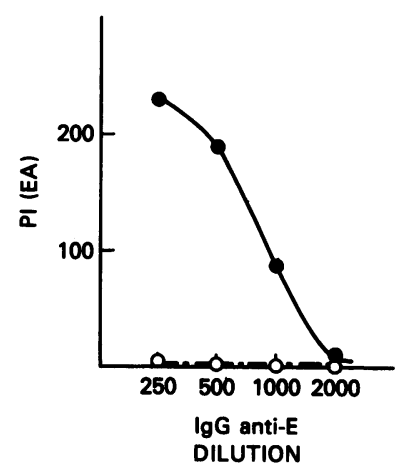

Figure 4. Inhibition of EA phagocytosis by fluid-phase $F\left(a^{\prime}\right)_{2}$ $\mathrm{M} 1 / 70$. The PI is plotted as a function of the amount of antiForssman IgG used to sensitize E in the absence $(\bullet)$ and presence (o) of $10 \mu \mathrm{g} / \mathrm{ml} \mathrm{F}\left(\mathrm{ab}^{\prime}\right)_{2} \mathrm{Ml} / 70$. The monoclonal antibody inhibits phagocytosis at every level of IgG sensitization.
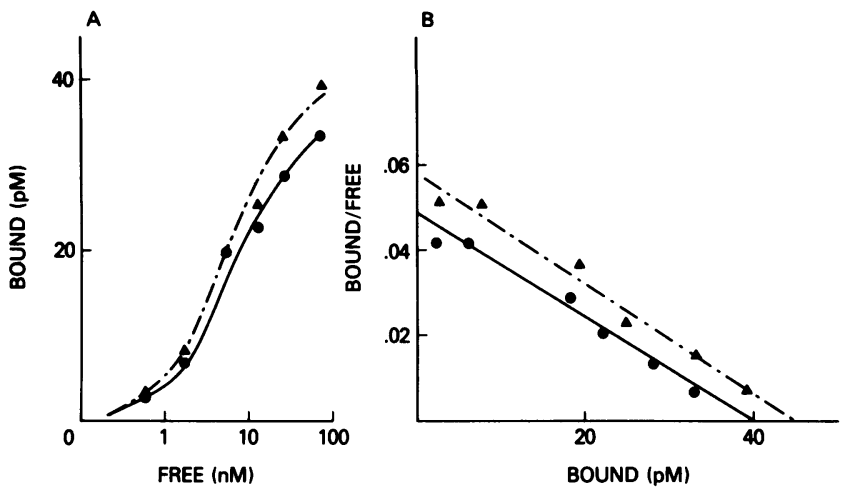

Figure. 5. Effect of $\mathrm{M} 1 / 70 \mathrm{~F}\left(\mathrm{ab}^{\prime}\right)_{2}$ on monomeric IgG binding to monocytes. The binding of monomeric IgG to monocytes in the presence $(\Delta)$ are absence $(\bullet)$ of $100 \mathrm{nM} \mathrm{M} 1 / 70 \mathrm{~F}\left(\mathrm{ab}^{\prime}\right)_{2}$ is compared. $(A)$ Data are plotted as a bound vs. log free (Klotz) plot. (B) Data are plotted as a bound/free vs. bound (Scatchard) plot. Neither $B_{\max }$ nor affinity of monocytes for IgG is affected by $\mathrm{M} 1 / 70 \mathrm{~F}\left(\mathrm{ab}^{\prime}\right)_{2}$.

$\mathrm{F}\left(\mathrm{ab}^{\prime}\right)_{2}$ vs. $32,000 \pm 9,000$ in buffer). Similarly the $K_{\mathrm{d}}$ of the receptor-ligand interaction was not different in the presence and absence of M1/70 $(9.50 \pm 4.2 \mathrm{nM}$ with M1/70 vs. $8.2 \pm 2.8$ $\mathrm{nM}$ in buffer). Thus, the inhibition of EA rosetting and phagocytosis by $\mathrm{M} 1 / 70$ could not be explained either by inhibition of monomeric IgG binding or by a change in monocyte Fc receptor number or affinity.

Next, we examined the effect of $M 1 / 70$ on aggregated IgG binding to monocytes. The receptor that mediates aggregated IgG binding to monocytes is not known. Only the $72-\mathrm{kD}$ high-affinity receptor has been shown to bind human IgG (27) and monomeric $\mathrm{IgG}$ inhibits the binding of erythrocytes opsonized with human $\operatorname{IgG}(27,29)$, which suggests that this is the receptor that mediates binding of both monomeric and aggregated IgG. When the binding of aggregated IgG to monocytes at $37^{\circ} \mathrm{C}$ was examined, $\mathrm{M} 1 / 70$ had a profound inhibitory effect (Table I). Because these incubation conditions might lead to both binding and internalization of aggregated $\mathrm{IgG}$ (30), we examined the effect of $\mathrm{M} 1 / 70 \mathrm{~F}\left(\mathrm{ab}^{\prime}\right)_{2}$ on the binding of aggregated $\operatorname{IgG}$ at $0^{\circ} \mathrm{C}$. The $\mathrm{F}\left(\mathrm{ab}^{\prime}\right)_{2}$ inhibited the binding of ${ }^{125} \mathrm{I}$-labeled aggregated $\mathrm{IgG}$, as it had at $37^{\circ} \mathrm{C}$ (data not shown). In addition, to ensure that surface binding was examined, aggregated IgG was labeled with fluorescein, which would lose fluorescence in the acidic endocytic vesicle upon internaliza-

Table I. Inhibition of Aggregated IgG Binding by $\mathrm{Ml} / 70 \mathrm{~F}\left(a b^{\prime}\right)_{2}$

\begin{tabular}{lcc}
\hline Incubation mixture & Quantity bound* & $\begin{array}{l}\text { Inhibition of } \\
\text { specific binding }\end{array}$ \\
\hline & $c p m$ & $\%$ \\
& & $\%$ \\
${ }^{125} \mathrm{I}-$ Aggregated IgG $(6.5 \mu \mathrm{g} / \mathrm{ml})$ only & $24,400 \pm 2,300$ & 0 \\
$+1 \mu \mathrm{g} / \mathrm{ml} \mathrm{M} 1 / 70 \mathrm{~F}^{\left(\mathrm{ab}^{\prime}\right)_{2}}$ & $16,400 \pm 2,400$ & 40 \\
$+5 \mu \mathrm{g} / \mathrm{ml} \mathrm{M} 1 / 70 \mathrm{~F}\left(\mathrm{ab}^{\prime}\right)_{2}$ & $8,300 \pm 1,400$ & 80 \\
$+220 \mu \mathrm{g} / \mathrm{ml}$ unlabeled agg-IgG & $4,100 \pm 300$ & 100
\end{tabular}

Binding occurred at $37^{\circ} \mathrm{C}$ and this represents both bound and internalized ligand.

* Results expressed as mean $\pm \mathrm{SD}$ of triplicate determinations. Both 1 and $5 \mu \mathrm{g} / \mathrm{ml}$ significantly inhibited ${ }^{125} \mathrm{I}$-aggregated $\mathrm{IgG}$ binding $(P$ $<0.05)$. 
tion (31). Monocyte-bound fluorescence was quantitated by fluorescence flow cytometry in the presence and absence of unlabeled aggregated IgG in buffer or in the presence of 125 nM M1/70. In both cases, the addition of unlabeled aggregated IgG demonstrated the existence of "specific fluorescence" which was saturable under the experimental conditions (Fig. 6). Like the binding of radiolabeled aggregates, but unlike the binding of monomeric $\mathrm{IgG}$, the binding of fluoresceinated $\mathrm{IgG}$ aggregates was markedly inhibited by $\mathrm{M} 1 / 70 \mathrm{~F}\left(\mathrm{ab}^{\prime}\right)_{2}$ (Fig. $6 \mathrm{C}$ ). The dose response of antibody showed $50 \%$ inhibition of aggregated IgG binding at $\sim 8 \mathrm{nM} \mathrm{F}\left(\mathrm{ab}^{\prime}\right)_{2}$ (Fig. $6 \mathrm{D}$ ), a value quite similar to the concentration that equivalently inhibited EA rosetting and phagocytosis. Thus, these data suggest that M1/70 inhibits the binding of aggregated IgG but not monomeric IgG to the high-affinity monocyte $\mathrm{Fc}$ receptor.

Aggregated IgG partially inhibits the binding of ${ }^{125} I-M 1 / 70$ to monocytes. To determine whether $\mathrm{M} 1 / 70$ inhibited aggregated IgG binding because of a physical association of Mac-1 and the IgG Fc receptor in the monocyte membrane, we examined whether aggregated IgG could inhibit ${ }^{125} \mathrm{I}-\mathrm{M} 1 / 70$ binding.
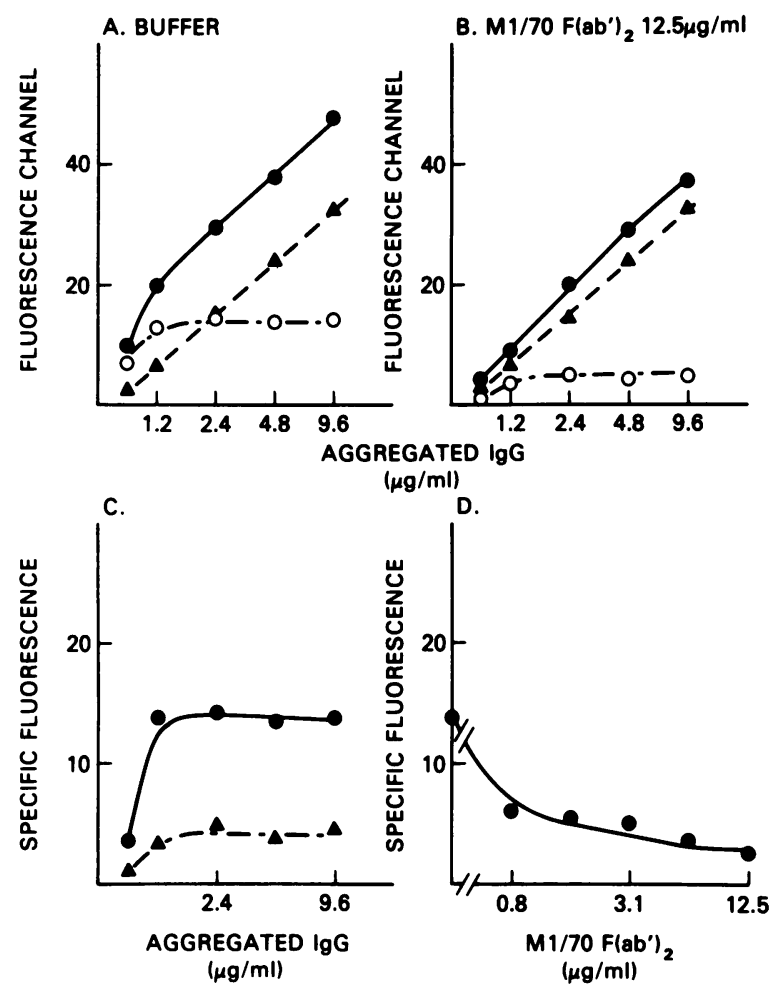

Figure 6. Effect of $\mathrm{M} 1 / 70 \mathrm{~F}\left(\mathrm{ab}^{\prime}\right)_{2}$ on aggregated IgG binding to monocytes. $(A)$ The binding of fluoresceinated aggregated IgG to monocytes in the absence ( $\bullet$ ) ("total binding") or presence ( $\Delta$ ) of excess unlabeled aggregated IgG ("nonspecific binding") was assessed by fluorescence flow cytometry. Specific fluorescence (O) represents the difference between the mean fluorescence channel for total and nonspecific binding at each input of fluorescenated $\mathrm{IgG}$. $(B)$ The same data are plotted for monocytes preincubated with $12.5 \mu \mathrm{g} / \mathrm{ml}$ $\mathrm{M} 1 / 70 \mathrm{~F}\left(\mathrm{ab}^{\prime}\right)_{2}$. $(C)$ The dose responses of specific fluorescence in the absence $(\bullet)$ or presence $(\triangle)$ of $12.5 \mu \mathrm{g} / \mathrm{ml} \mathrm{M} 1 / 70 \mathrm{~F}\left(\mathrm{ab}^{\prime}\right)_{2}$ are compared. M1/70 inhibits aggregated IgG binding to monocytes. $(D)$ The dose response of $\mathrm{Ml} / 70 \mathrm{~F}\left(\mathrm{ab}^{\prime}\right)_{2}$ inhibition of aggregated IgG binding is shown by plotting the specific fluorescence at an input of 2.4 $\mu \mathrm{g} / \mathrm{ml}$ aggregated $\mathrm{IgG}$ in the presence of increasing concentrations of $\mathrm{M} 1 / 70 \mathrm{~F}\left(\mathrm{ab}^{\prime}\right)_{2}$. ID $\mathrm{ID}_{50}$ for $\mathrm{M} 1 / 70 \mathrm{~F}\left(\mathrm{ab}^{\prime}\right)_{2}$ is $\sim 8 \mathrm{nM}$.
If there were a physical association between the two molecules, reciprocal inhibition by their ligands might be expected. Aggregated IgG partially inhibited the binding of radiolabeled M1/70 to monocytes (Fig. 7 A). $\sim 56,000$ molecules of M1/70 were bound per monocyte at saturation in the absence of aggregated IgG. This number was reduced by $37.2 \pm 1.6 \%(n=7)$ by $150 \mu \mathrm{g} / \mathrm{ml}$ aggregated IgG. As shown in Fig. $7 A$, increasing the concentration of aggregated IgG from 100 to $250 \mu \mathrm{g} / \mathrm{ml}$ had no effect on the ability of aggregated IgG to inhibit M1/70 binding. Thus, $\sim 40 \%$ of $\mathrm{Ml} / 70$ binding was inhibitable by the prior binding of aggregated IgG to monocytes. As shown in Fig. $7 \mathrm{~B}$, this effect of aggregated $\mathrm{IgG}$ is specific for $\mathrm{M} 1 / 70$, since the binding of ${ }^{125} \mathrm{I}-3 \mathrm{D} 9$ to monocytes was unaffected by the presence of aggregated IgG. Moreover, ${ }^{125} \mathrm{I}-\mathrm{M} 1 / 70$ binding was not inhibited by $10 \mu \mathrm{g} / \mathrm{ml}$ monomeric $3 \mathrm{D} 9$, a concentration 10 times that required to saturate cell surface CR1. Finally, M1/70 binding was not inhibited by $10 \mu \mathrm{g} / \mathrm{ml}$ monomeric human IgG, a concentration about six times the $K_{\mathrm{d}}$ for IgG receptor binding on monocytes. These data suggested that there might be two populations of molecules recognized by M1/70, which could be distinguished by the ability of aggregated IgG to interfere with antigen recognition by the monoclonal antibody.

Surface-bound anti-Mac-1 $F\left(a b^{\prime}\right)_{2}$ have no effect on EA rosetting and phagocytosis. The discovery that M1/70 inhibited aggregated IgG binding without affecting the interaction of monomeric IgG with the Fc receptor suggested that the inhibition of EA binding by M1/70 did not involve a direct inhibition of opsonin binding to the Mac-1 molecule. However, other molecules that apparently do not directly bind IgG-Fc may modulate $\mathrm{Fc}$ receptor function even when bound to the solid phase (32). Therefore, we investigated the ability of solid-phase $\mathrm{M} 1 / 70 \mathrm{~F}\left(\mathrm{ab}^{\prime}\right)_{2}$ to remove the functional antigens involved in EC3bi rosetting and in EA rosetting and phagocytosis from the apical surface of the monocytes.

As previously reported for other anti-Mac-1 antibodies (3), monocytes adherent for $1 \mathrm{~h}$ to wells coated with $5 \mu \mathrm{g} / \mathrm{ml}$ $\mathrm{M} 1 / 70 \mathrm{~F}\left(\mathrm{ab}^{\prime}\right)_{2}$ bound $77 \%$ fewer EC3bi (AI $=118 \pm 28(\mathrm{SEM}), n$ $=8$ ) than monocytes adherent to albumin-coated wells (AI
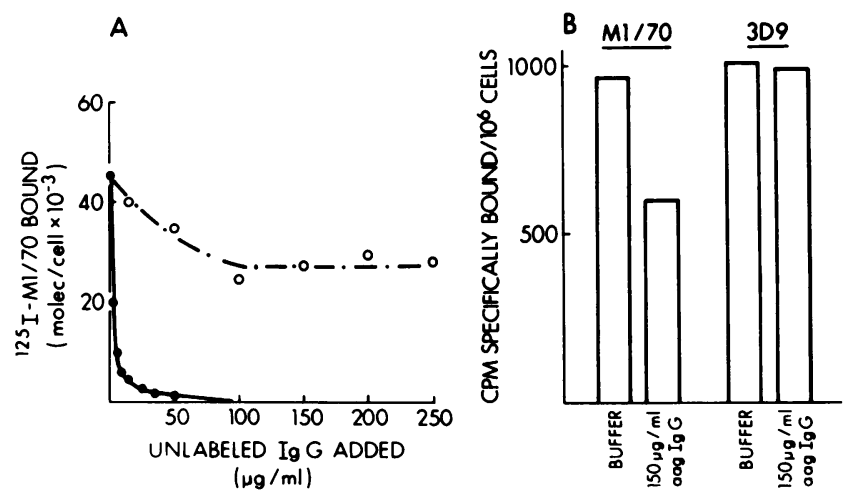

Figure 7. Effect of aggregated IgG on the binding of M1/70. (A) The ability of unlabeled M1/70 (•) and unlabeled aggregated human IgG (O) to inhibit the binding of ${ }^{125} \mathrm{I}-\mathrm{M} 1 / 70$ to cells is compared. Binding of radiolabeled $M 1 / 70$ is efficiently inhibited by $M 1 / 70$, and is partially inhibited by aggregated IgG. (B) Aggregated IgG inhibits the binding of M1/70 to Mac-1 but not of 3D9 to CR1. This demonstrates specificity of the inhibitory effect of aggregated IgG on M1/70 binding. 


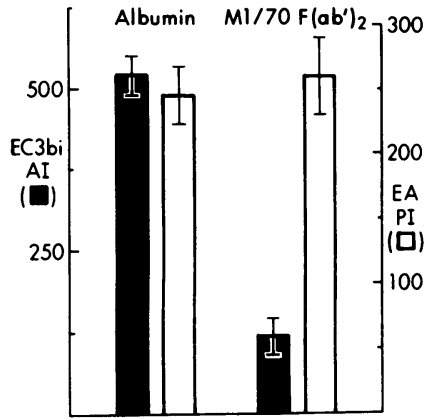

Figure 8. Solid-phase M1/70 inhibits EC3bi rosettes but not EA phagocytosis. After $1 \mathrm{~h}$ of adherence of monocytes, solidphase $\mathrm{M} 1 / 70 \mathrm{~F}\left(\mathrm{ab}^{\prime}\right)_{2}$ inhibit EC3bi rosettes by $77 \%$ (solid bars) compared with BSA, while the solid phase antibody has no effect on EA phagocytosis (open bars).

$=519 \pm 31, n=8)$. Strikingly, coated wells with even $50 \mu \mathrm{g} / \mathrm{ml}$ $\mathrm{F}\left(\mathrm{ab}^{\prime}\right)_{2}$ did not inhibit EA rosetting or phagocytosis (Fig. 8). The PI for monocytes on albumin-coated plates was $245 \pm 22$ (SEM, $n=18$ ); on $\mathrm{F}\left(\mathrm{ab}^{\prime}\right)_{2}$-coated plates the PI was $261 \pm 30$ ( $n$ $=8)$. The AI for EA was similarly unaffected by coating plates with $\mathrm{M} 1 / 70 \mathrm{~F}\left(\mathrm{ab}^{\prime}\right)_{2}$. However, addition of fluid-phase $\mathrm{M} 1 / 70$ $F\left(a b^{\prime}\right)_{2}$ to cells adherent to wells coated with these same $F\left(a b^{\prime}\right)_{2}$ did inhibit EA phagocytosis, and the dose response of inhibition by fluid-phase $\mathrm{M} 1 / 70 \mathrm{~F}\left(\mathrm{ab}^{\prime}\right)_{2}$ was essentially identical for BSA- and M1/70-coated plates (Fig. 9). Experiments with Mo-1 $\mathrm{F}\left(\mathrm{ab}^{\prime}\right)_{2}$ gave precisely the same results. Plate-bound $\mathrm{F}\left(\mathrm{ab}^{\prime}\right)_{2}$ inhibited EC3bi binding in a dose-response fashion but had no effect on EA rosetting (Fig. 10). The effect of platebound Mo-1 on EC3bi rosetting was relatively independent of the amount of $\mathrm{C} 3 \mathrm{bi}$ on the target, since similar dose responses of inhibition were seen for EC3bi with AI ranging from 500 to 2,000. EA binding was not affected for targets bearing different amounts of IgG giving AI between 100 and 500. When monocytes were plated onto a surface which had been incubated with $100 \mu \mathrm{g} / \mathrm{ml} \mathrm{F}\left(\mathrm{ab}^{\prime}\right)_{2}$ Mo-1, EC3bi rosettes were inhibited by $80 \%$ but EA rosettes were uninhibited compared to BSAcoated surfaces (Fig. 11). Nonetheless, $50 \mu \mathrm{g} / \mathrm{ml} \mathrm{F}\left(\mathrm{ab}^{\prime}\right)_{2}$ Mo-1 added to the fluid phase inhibited EA rosettes on both BSAand Mo-1-coated surfaces.

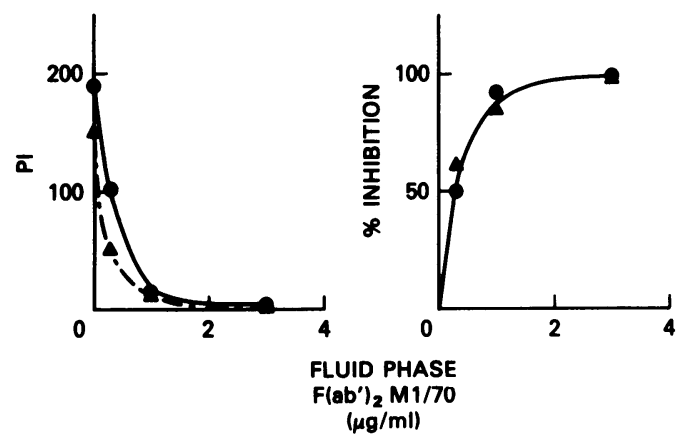

Figure 9. Lack of effect of solid-phase M1/70 on the ability of fluidphase M1/70 to inhibit EA phagocytosis. The effect of fluid-phase $\mathrm{M} 1 / 70 \mathrm{~F}\left(\mathrm{ab}^{\prime}\right)_{2}$ on EA phagocytosis by monocytes adherent to albumin-coated plates $(\bullet)$ and $\mathrm{M} 1 / 70 \mathrm{~F}\left(\mathrm{ab}^{\prime}\right)_{2}$-coated plates $(\Delta)$ is compared. There is no difference in EA phagocytosis by monocytes plated on albumin or M1/70 coated surfaces as shown by the data on the ordinate in both panels. Moreover, the ability of fluid-phase $\mathrm{M} 1 / 70 \mathrm{~F}\left(\mathrm{ab}^{\prime}\right)_{2}$ to inhibit EA phagocytosis by monocytes on $\mathrm{mAB}-$ coated surfaces remains intact. (Left panel) PI is plotted as a function of fluid-phase $\mathrm{M} 1 / 70 \mathrm{~F}\left(\mathrm{ab}^{\prime}\right)_{2}$ for monocytes on surfaces incubated with $50 \mu \mathrm{g} / \mathrm{ml}$ of either albumin (๑) or $\mathrm{Ml} / 70 \mathrm{~F}\left(\mathrm{ab}^{\prime}\right)_{2}(\Delta)$. (Right panel) Data are presented as percent inhibition of phagocytosis compared to the absence of fluid-phase M1/70.

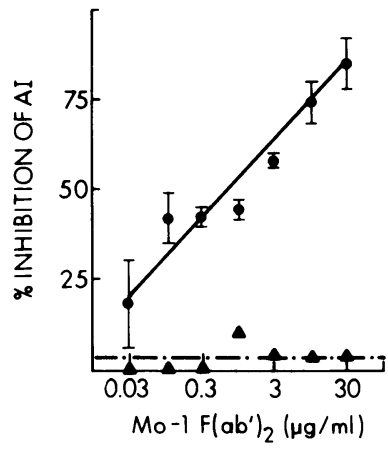

These experiments suggested that there was a population of Mac-1 molecules which remained on the apical surface of monocytes adherent to anti-Mac-1-coated wells. Ligation of these molecules on the apical surface resulted in inhibition of IgG-mediated rosetting and phagocytosis just as it did on monocytes from which no Mac-1 antigen had been removed from the apical surface. To test whether this remarkable effect could be abolished by allowing the monocytes to adhere to $\mathrm{M} 1 / 70 \mathrm{~F}\left(\mathrm{ab}^{\prime}\right)_{2}$-coated wells for longer periods of time, a kinetic experiment was performed (Fig. 12). If apical Mac-1 molecules could eventually be brought to the adherent cell surface, the effect of fluid-phase M1/70 on EA phagocytes would be abolished. When monocytes were adhered to $\mathrm{M} 1 / 70 \mathrm{~F}\left(\mathrm{ab}^{\prime}\right)_{2}$-coated surfaces, subsequent EC3bi attachment to the monocytes was inhibited by $75 \%$ at $1 \mathrm{~h}$ and by $90 \%$ at $4 \mathrm{~h}$, suggesting that some decrease in apically expressed Mac-1 had occurred with the longer incubation. On the other hand, even after $4 \mathrm{~h}$, there was no difference in phagocytosis between monocytes plated on BSA and those plated on $45 \mu \mathrm{g} / \mathrm{ml} \mathrm{M} 1 / 70 \mathrm{~F}\left(\mathrm{ab}^{\prime}\right)_{2}$. Moreover, there was no decrease in the ability of fluid-phase M1/70 $\left.\mathrm{F}(\mathrm{ab})_{2}\right)_{2}$ to inhibit EA phagocytosis, even after the monocytes had been adherent to antibody-coated plates for $4 \mathrm{~h}$. Dose-response curves showed that monocytes plated onto wells coated with $5 \mu \mathrm{g} / \mathrm{ml} \mathrm{M} 1 / 70 \mathrm{~F}\left(\mathrm{ab}^{\prime}\right)_{2}$ were equally inhibited in their binding of EC3bi as those cultured on surfaces coated with 45 $\mu \mathrm{g} / \mathrm{ml} \mathrm{F}\left(\mathrm{ab}^{\prime}\right)_{2}$. However, even the highest dose of antibody

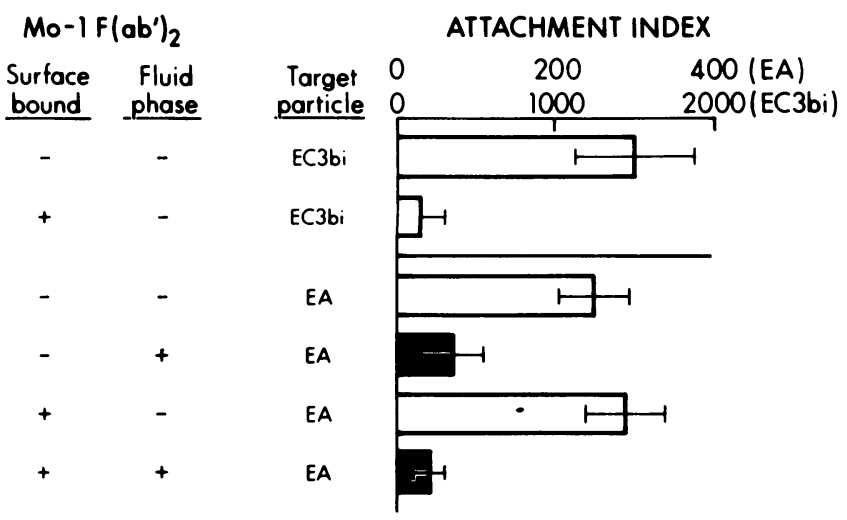

Figure 11. Fluid-phase Mo-1 $\mathrm{F}\left(\mathrm{ab}^{\prime}\right)_{2}$ inhibit EA attachment to monocytes adherent to Mo-1-coated surfaces. Monocytes were allowed to adhere to surfaces coated with $100 \mu \mathrm{g} / \mathrm{ml} \mathrm{Mo-1} \mathrm{F}\left(\mathrm{ab}^{\prime}\right)_{2}$. This led to $>80 \%$ reduction of EC3bi rosettes, but no reduction of EA rosettes. Addition of $50 \mu \mathrm{g} / \mathrm{ml} \mathrm{Mo-1} \mathrm{to} \mathrm{the} \mathrm{fluid} \mathrm{phase} \mathrm{inhibited} \mathrm{EA} \mathrm{binding}$ by $70 \%$ to cells which were adherent to Mo-1-coated surfaces $(n=3)$. 

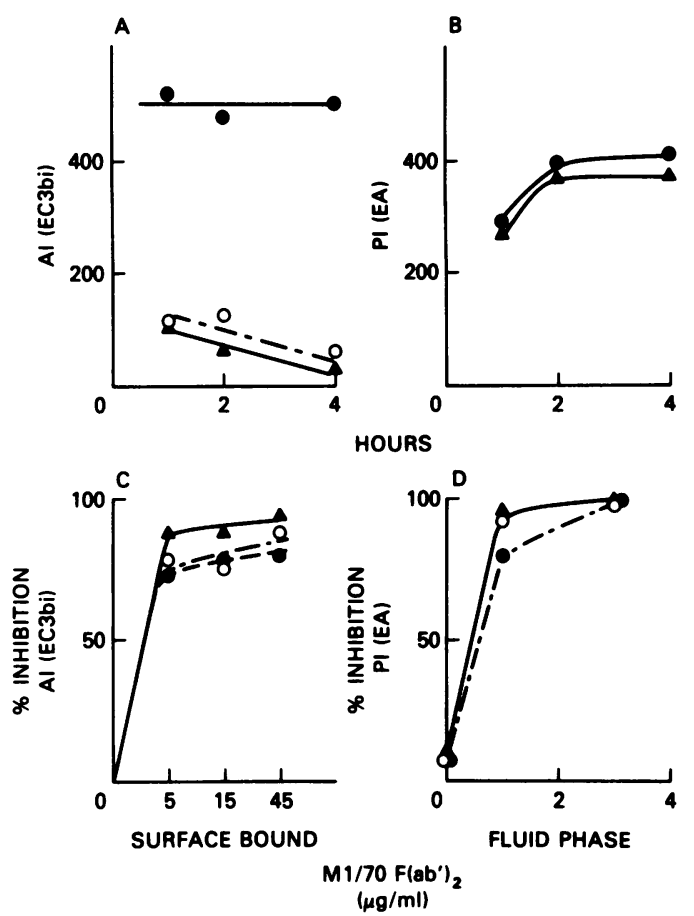

Figure 12. Kinetics and dose response of $\mathrm{M} 1 / 70 \mathrm{~F}\left(\mathrm{ab}^{\prime}\right)_{2}$ inhibition of EC3bi rosetting the EA phagocytosis. $(A)$ Rosetting by adherent monocytes as a function of time. EC3bi rosettes remain constant over a $4-\mathrm{h}$ period on surfaces coated with $50 \mu \mathrm{g} / \mathrm{ml} \mathrm{BSA} \mathrm{( \bullet ).} \mathrm{If}$ monocytes are adherent to surfaces coated with $5 \mu \mathrm{g} / \mathrm{ml}$ (O) or 45 $\mu \mathrm{g} / \mathrm{ml}(\Delta) \mathrm{M} 1 / 70 \mathrm{~F}\left(\mathrm{ab}^{\prime}\right)_{2}$, rosettes are $75 \%$ decreased by $1 \mathrm{~h}$ of incubation. Incubation for $4 \mathrm{~h}$ on M1/70-coated surfaces decreases the Al further, to $\sim 5 \%$ of control values. $(B)$ Phagocytosis by monocytes adherent to albumin $(\bullet)$ or M1/70- $(45 \mu \mathrm{g} / \mathrm{ml})(\Delta)$ coated plates as a function of time. The PI increases with time for monocytes on both surfaces. Even after $4 \mathrm{~h}$, there is no effect of surface bound $\mathrm{M} 1 / 70$ on the PI. $(C)$ Inhibition of EC3bi attachment as a function of time and dose of $\mathrm{M} 1 / 70 \mathrm{~F}\left(\mathrm{ab}^{\prime}\right)_{2}$. The AIs for monocytes plated on surfaces incubated with various concentrations of $\mathrm{M} 1 / 70 \mathrm{~F}\left(\mathrm{ab}^{\prime}\right)_{2}$ are compared after $1(\bullet), 2(0)$, and $4 \mathrm{~h} \mathrm{( \Delta )}$ of incubation. Inhibition is almost complete after $1 \mathrm{~h}$ of incubation, even on surfaces coated with only $5 \mu \mathrm{g} / \mathrm{ml} \mathrm{M} 1 / 70 \mathrm{~F}\left(\mathrm{ab}^{\prime}\right)_{2}$. (D) Inhibition of EA phagocytosis by fluid-phase $\mathrm{M} 1 / 70 \mathrm{~F}\left(\mathrm{ab}^{\prime}\right)_{2}$ as a function of time. Monocytes were adherent to surfaces coated with $45 \mu \mathrm{g} / \mathrm{ml} \mathrm{M} 1 / 70 \mathrm{~F}\left(\mathrm{ab}^{\prime}\right)_{2}$. Dose response for fluid-phase M1/70 inhibition of EA phagocytosis was similar after $1(\bullet), 2(0)$, and $4 \mathrm{~h}(\Delta)$ of adherence. The ability of fluid phase $\mathrm{M} 1 / 70 \mathrm{~F}\left(\mathrm{ab}^{\prime}\right)_{2}$ to inhibit EA phagocytosis by monocytes adherent to albumin-coated surfaces was also unaffected by time of adherence (data not shown).

used to coat surfaces had no effect on EA phagocytosis or on subsequent inhibition of phagocytosis by additional fluidphase $\mathrm{M} 1 / 70 \mathrm{~F}\left(\mathrm{ab}^{\prime}\right)_{2}$. These results showed that Mac-1 molecules involved in EC 3 bi rosetting rapidly disappeared from the upper surface of the cell after adherence to M1/70-coated wells. In contrast, the antigen recognized by $M 1 / 70$ which is involved in modulation of EIgG ingestion remained on the upper surface of the monocytes even after prolonged periods of adherence to M1/70-coated plates. These data indicate that M1/70-mediated inhibition of EC3bi binding is fundamentally different from M1/70-mediated inhibition of EA ingestion. In conjunction with the failure of aggregated $\mathrm{IgG}$ to completely inhibit M1/70 binding, these data suggest that there may be two populations of Mac-1 on the cell surface, only one of which is involved in the inhibition of EA binding and phagocytosis by anti-Mac-1 $\mathrm{F}\left(\mathrm{ab}^{\prime}\right)_{2}$.

Surface-bound M1/70 modulates Mac-1 antigen. When monocytes were allowed to adhere for $2 \mathrm{~h}$ to tissue culture plates coated with an irrelevant antibody (3D9), $~ 39,000$ molecules of ${ }^{125} \mathrm{I}-\mathrm{M} 1 / 70$ bound per cell at $4^{\circ} \mathrm{C}$ (Table II). In these antigen modulation experiments, intact $\mathrm{M} 1 / 70 \mathrm{IgG}$ was used to coat the surface of the tissue culture dish. It has been suggested that the use of intact IgG rather than $F\left(a b^{\prime}\right)_{2}$ creates a tight junction between the monocyte and the plastic, which prevents diffusion of the radiolabelled probe to the adherent surface of the cell (33). This was confirmed for both 3D9 and M1/70 IgG in our system, because of the presence of "black holes" on fluorescence microscopy in experiments performed as described by Wright and Silverstein (33). This demonstrated that fluoresceinated anti-mouse IgG was unable to diffuse below the adherent monocytes plated onto surfaces nonspecifically coated with IgG. As described above, 3D9 does not block the binding of M1/70 to monocytes in the fluid phase. Thus the difference between the number of M1/70 bound specifcally to adherent monocytes plated onto 3D9-coated surfaces $(39,000$ per cell) and to fluid-phase monocytes $(56,000$ per cell) represents the inaccessibility of Mac-1 on the adherent monocyte undersurface to fluid-phase ${ }^{125} \mathrm{I}-\mathrm{M} 1 / 70$.

Adherence to tissue culture wells coated with $5 \mu \mathrm{g} / \mathrm{ml}$ M1/70 IgG, which maximally inhibited EC3bi rosettes, reduced ${ }^{125} \mathrm{I}-\mathrm{M} 1 / 70$ binding by only $45 \%$ after $2 \mathrm{~h}$ of adherence (Table II). As was true for EC3bi rosetting, somewhat fewer antibody molecules bound to cells that had been incubated on an M1/70-coated surface for $4 \mathrm{~h}$ (40\% of control). Treating cells with $10 \mu \mathrm{g} / \mathrm{ml}$ cycloheximide, to prevent synthesis of new Mac-1 antigen during the adherence period, did not affect ${ }^{125} \mathrm{I}-\mathrm{M} 1 / 70$ binding to cells plated on antibody coated or control wells. Thus these data demonstrate that a significant amount of $\mathrm{Ml} / 70$ antigen remained on the apical surface of the cell, even after prolonged adherence to M1/70-coated surfaces. The absence of an effect of cycloheximide on M1/70 binding suggested that newly synthesized and inserted Mac-1 antigen does not affect the distribution of this cell surface antigen during the course of these experiments.

Table II. Modulation of Mac-1 Antigen by Surface-bound M1/70

\begin{tabular}{|c|c|}
\hline Surface coating & ${ }^{125} \mathrm{I}-\mathrm{Ml} / 70$ bound $^{*}$ \\
\hline & molecules/monocyte \\
\hline 3D9 & 39,000 \\
\hline \multicolumn{2}{|l|}{ M1/70 } \\
\hline (2-h adherence) & 22,500 \\
\hline \multicolumn{2}{|l|}{$\mathrm{M} 1 / 70$} \\
\hline $\begin{array}{l}\text { (2-h adherence } \\
+ \text { cycloheximide) }\end{array}$ & 21,000 \\
\hline \multicolumn{2}{|l|}{$\mathrm{M} 1 / 70$} \\
\hline (4-h adherence) & 15,000 \\
\hline \multicolumn{2}{|l|}{$\mathrm{M} 1 / 70$} \\
\hline $\begin{array}{l}\text { (4-h adherence } \\
\text { + cycloheximide) }\end{array}$ & 14,500 \\
\hline
\end{tabular}

* Data represent the mean of two to five experiments, each done in duplicate. 


\section{Discussion}

In this work we have performed a detailed study of the inhibition of IgG-mediated phagocytosis by monoclonal antibodies directed against the Mac-1 antigen. $\mathrm{M} 1 / 70 \mathrm{~F}\left(\mathrm{ab}^{\prime}\right)_{2}$ in the fluid phase inhibited EA binding and phagocytosis at low concentrations, whereas about 10 times as much Mo-1 $\mathrm{F}\left(\mathrm{ab}^{\prime}\right)_{2}$ was required for an equivalent effect on $\mathrm{Fc}$ receptor function. Several lines of evidence demonstrated that this inhibition did not result from residual contamination of the $F\left(a b^{\prime}\right)_{2}$ with whole IgG, which might bind quite avidly to Fc receptors (25). First, Western blots capable of detecting as little as $4.5 \mathrm{ng}$ of intact $\mathrm{M} 1 / 70 \mathrm{IgG}$ showed none in $1.5 \mu \mathrm{g}$ of $\mathrm{F}\left(\mathrm{ab}^{\prime}\right)_{2}$. Moreover, incubation of monocytes with $10 \mu \mathrm{g} / \mathrm{ml} \mathrm{F}\left(\mathrm{ab}^{\prime}\right)_{2} \mathrm{M} 1 / 70$ did not affect monomeric IgG binding to monocytes, demonstrating that even these high concentrations of monoclonal antibody did not interact with cellular Fc receptors. Finally, neither $\mathrm{M} 1 / 70$ nor Mo-1 $\mathrm{F}\left(\mathrm{ab}^{\prime}\right)_{2}$ affected EA binding or phagocytosis when bound to a solid phase in concentrations that nearly completely inhibited EC3bi binding. Thus, the inhibition of EA rosetting and phagocytosis by anti-Mac- $1 \mathrm{~F}\left(\mathrm{ab}^{\prime}\right)_{2}$ occurred because of binding to their cell surface epitopes and not because of competition with $\mathrm{IgG}$ opsonized erythrocytes for $\mathrm{Fc}$ receptors.

We explored the mechanism by which these $F\left(a b^{\prime}\right)_{2}$ inhibited IgG-mediated erythrocyte binding and phagocytosis. First, we considered the possibility that these antibodies recognized a receptor for IgG. There are two reported IgG binding molecules on human monocytes (27). One receptor of $72 \mathrm{kD}(28)$ has high affinity for monomeric human IgG1 and IgG3 (20). The other receptor of $40 \mathrm{kD}$ has thus far only been shown to bind particulate targets bearing mouse IgG 1 . Neither receptor has a structure similar to that reported for the Mac-1 antigen. Moreover, the observation that plate-bound $F\left(a^{\prime}\right)_{2}$ anti-Mac1 did not affect EA rosetting or phagocytosis, while modulating Mac-1 antigen, suggested that Mac-1 was not itself another IgG Fc receptor. We next considered the possibility that by binding to its membrane antigen M1/70 or Mo-1 might alter the ability of $\mathrm{IgG} \mathrm{Fc}$ receptors to recognize monomeric ligands. This proved not to be the case, since neither total IgG binding, receptor affinity, nor receptor number was affected by the presence of $M 1 / 70$. Because our data demonstrated the Mac-1 was not an IgG receptor nor did it alter the affinity of monomeric IgG for the $\mathrm{Fc}$ receptor, we considered the possibility that M1/70 and Mo-1 inhibited Fc receptor function because it was spacially associated with an IgG receptor in the monocyte membrane. This hypothesis was supported by the experimental data which showed that $\mathrm{M} 1 / 70 \mathrm{~F}\left(\mathrm{ab}^{\prime}\right)_{2}$ inhibited the binding of aggregated human IgG as well as EA and that, conversely, aggregated IgG could partially inhibit M1/70 binding. The receptors for binding of aggregated IgG to monocytes are less well understood than for the binding of IgG monomer. While the 72-kD high-affinity IgG receptor is undoubtedly involved, it is possible that a lower-affinity receptor contributes to the binding of IgG complex as well (34). Thus, it is possible that the inhibition of aggregated IgG binding by M1/70 may occur because of interference with either or both monocyte IgG Fc receptors. The ability of whole IgG2a Mo-1 to inhibit EA binding at low concentration suggests that this binding is mediated by the high-affinity IgG receptor, since this molecule recognizes mouse IgG2a extremely well (35). In contrast 3D9, an IgG1, only minimally inhibits EA binding, suggesting that the receptor for mouse IgG1 contributes minimally to EA binding.

It is clear that the inhibition of EA binding by anti-Mac-1 antibodies is epitope specific, since M1/70 is a far better inhibitor than Mo-1, while OKM1 and IgM Mo-1 (14) do not inhibit EA binding and ingestion at all. This does not correlate with the ability of these antibodies to inhibit EC3bi binding, since Mo-1 is about 10-fold better at this latter function than M1/70. This suggests that the increased efficacy of $\mathrm{M} 1 / 70$ as an inhibitor of EA binding occurs because it recognizes a site on Mac-1 which is involved in its association with the IgG Fc receptor. The existence of distinct functional domains on the Mac-1 molecule has been previously suggested (36). Since aggregation of $\mathrm{Fc}$ receptors is required for both IgG rosetting and phagocytosis (37), it is possible that $M 1 / 70$, and to a lesser extent Mo-1, interferes with this function. This is consistent with either an active or a passive role for the Mac-1 antigen itself in IgG receptor aggregation. While it is possible that Mac-1 and, in particular, the domain recognized by $\mathrm{Ml} / 70$, play an essential role in the aggregation of $\mathrm{IgG}$ receptors, it is also possible that the monoclonal antibody, bound to a nondiffusing protein, simply sterically hinders the immune complex-mediated receptor aggregation. Ross et al. have reported that M1/70 inhibits IgG-mediated phagocytosis by PMN without inhibiting rosettes (24). Whether this represents a difference between monocytes and PMN or reflects some other difference between work of Ross et al. and our own is unknown.

If Mac-1 is involved in the aggregation of monocyte $\mathrm{Fc}$ receptors by ligand, it may well be important for receptor aggregation phenomena in general. This may explain the involvement of Mac-1 in phagocyte binding to endothelial cells (34), to fibronectin-coated microspheres (5), and in the other phenomena in which Mac-1 is not the ligand receptor. Interestingly, Nauseef et al. recently have suggested that Mac-1 antigen is involved in linking receptor-ligand complexes to the cytoskeleton (38), a process which in some cases requires receptor aggregation.

We next asked whether association with the binding of multimeric IgG was a property of all Mac-1 molecules. Several experiments suggested that only a fraction of the cell surface Mac-1 was associated with IgG receptor-mediated rosetting and phagocytosis. First, M1/70 binding was only partially inhibited by aggregated IgG. About $40 \%$ fewer M1/70 bound in the presence of aggregated IgG than to control cells. Second, although $60 \%$ of Mac-1 antigen could be removed from the upper surface of monocytes by plate-bound M1/70, this had no effect on EA rosettes or phagocytosis. This suggested that the $40 \%$ of the Mac-1 remaining on the monocyte upper surface represented those molecules important in facilitating the binding of multivalent IgG ligands or EA targets. This was strikingly different than the case of EC3bi, for which modulation of Mac-1 by surface-bound M1/70 led or Mo- 1 to a $90 \%$ decrease in rosetting function. This also clearly distinguishes the inhibitory effects of anti-Mac-1 antibodies on Fc receptor function from those of mannose-terminated glycoproteins, which inhibit IgG-mediated phagocytosis even when bound to a solid phase (32). Third, fluid-phase $\mathrm{M} 1 / 70$ or $M o-1 F\left(a^{\prime}\right)_{2}$ remained competent to inhibit EA binding and ingestion, even after modulation of Mac-1 antigen by solid-phase antibodies. This again suggested that the Mac-1 molecules relevant to EA 
binding and phagocytosis remained on the nonadherent surface of the monocytes, essentially unaffected by the solid-phase antibody which had successfully removed EC3bi rosetting function.

There are at least two possible explanations for the difference between the effects of solid-phase M1/70 on EC3bi rosettes and on EA rosetting and phagocytosis. One possibility is that $\mathrm{M} 1 / 70$ recognizes functionally distinct molecules on the monocyte plasma membrane; the second is that all Mac-1 molecules are functionally identical, but there are quantitative differences between the effects of $\mathrm{M} 1 / 70$ on $\mathrm{C} 3 \mathrm{bi}$ receptor and IgG receptor function. While our experiments do not definitely distinguish these possibilities, we favor the former explanation. If all cell surface molecules on monocytes recognized by Mo-1 and M1/70 are functionally identical, our data suggest that fewer unligated Mac-1 molecules on the apical surface are required for effective EA phagocytosis than for EC3bi rosettes, since higher concentrations of fluid-phase Mo-1 and M1/70 are required to inhibit EA rosetting and phagocytosis than EC3bi rosettes (Figs. 2 and 3). This is consistent with our observation that EA phagocytosis proceeds normally in cells adherent to M1/70-coated plates, when only $15,000 \mathrm{M} 1 / 70$ binding sites are available on the apical surface, while EC3bi rosetting is $90 \%$ inhibited in these cells. However, addition of enough $\mathrm{M} 1 / 70 \mathrm{~F}\left(\mathrm{ab}^{\prime}\right)_{2}$ to the fluid phase to block EC3bi rosettes by $90 \%$ results in $>75 \%$ inhibition of EA phagocytosis (Fig. 2). Thus, if all Mac-1 molecules on the cell surface were interchangeable, EA phagocytosis should have been decreased by at least $75 \%$ by the surface bound $\mathrm{M} 1 / 70$. Since it was not, it is unlikely that quantitative differences between the requirements for Mac-1 in EC3bi rosetting and in EA binding and phagocytosis can explain our observations fully. Moreover, the hypothesis that all Mac-1 are functionally identical requires that unligated Mac-1 play an active role in both CR3 and IgG Fc receptor-mediated rosetting. There is no evidence that this is the case for EA binding, since the monocyte Fc receptors are clearly distinct from the Mac-1 molecule. Instead, our experimental data show that only fluid-phase $\mathrm{M1} / 70$ has an inhibitory effect on EA rosetting and phagocytosis. This suggests that the Mac-1 antigens which are involved in this process remain on the apical surface of the cell even when cells are plated onto M1/70 coated surfaces. This interpretation is supported by the finding that $40 \%$ of Mac-1 antigen remains on the apical monocyte membrane, even after $4 \mathrm{~h}$ or adherence to an M1/70-coated surface.

Second, the fact that aggregated IgG can only inhibit $40 \%$ of M1/70 binding to monocytes is consistent with the hypothesis that there are two pools of Mac-1 on the cell surface, one associated with IgG Fc receptor function and one unassociated. It would be much more difficult to explain this partial inhibition, and its specificity for the Mac-1 antigen, with an hypothesis which assumed that all Mac-1 antigens are functionally identical. It is interesting that the percentage of $\mathrm{M} 1 / 70$ binding that is inhibited by aggregated IgG is similar to the percentage of $\mathrm{M} 1 / 70$ binding remaining on the apical surface of monocytes adherent to M1/70-coated surfaces. Together with the functional data that demonstrate that the ability of M1/70 to inhibit IgG receptor function is unaffected by solid-

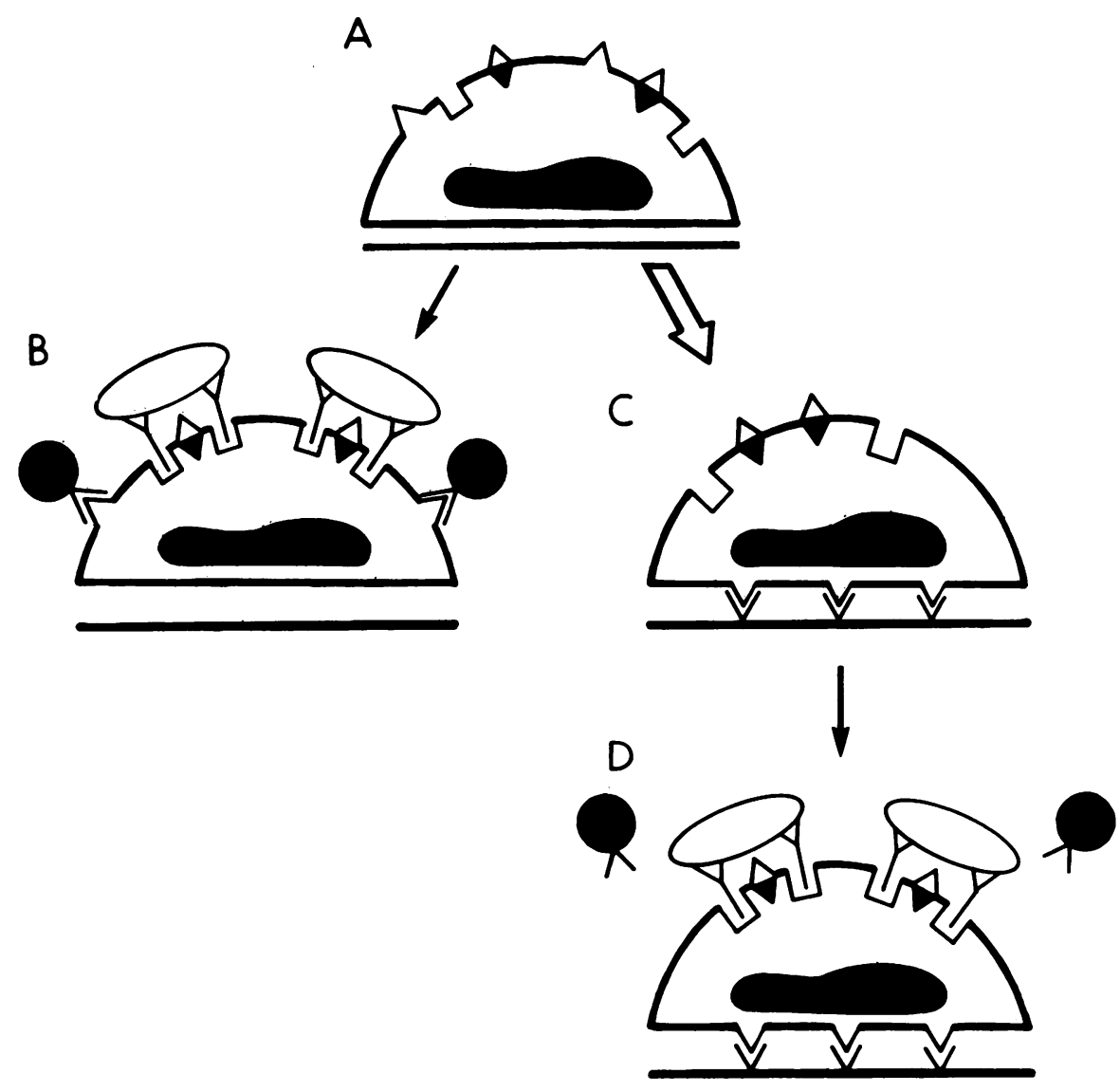

Figure 13. Proposed mechanism for differential effects of $\mathrm{M} 1 / 70 \mathrm{~F}\left(\mathrm{ab}^{\prime}\right)_{2}$ on EA and EC3bi binding. The data suggest that these are diffusing $(\Delta)$ and non diffusing $(\diamond)$ forms of Mac-1 antigen in the monocyte membrane. The nondiffusing form of the antigen occurs in association with $\mathrm{Fc}$ receptors upon EA rosetting; the diffusing form can bind EC3bi $(B)$. Thus, when monocytes are plated upon M1/70 coated surfaces, the diffusing form of Mac-1 is removed from the apical surface of the cell, but the nondiffusing form is not $(C)$. As a result of EC3bi rosetting is inhibited by solid-phase $M 1 / 70$, but EA rosetting is not $(D)$. Since the nondiffusing form of the molecule remains on the apical surface of the cell, it is accessible to fluidphase M1/70. Thus fluid-phase M1/70 $F\left(a b^{\prime}\right)_{2}$ are equally inhibitory for EA rosetting on control and M1/70-coated surfaces. 
phase $M 1 / 70$, these data suggest that the nondiffusing pool of Mac-I antigen which remains on the apical surface of cells adherent to Mo-1 or M1/70-coated surfaces and the Mac-1 antigens involved in $\mathrm{Fc}$ receptor function are identical.

We suggest that the Mac-1 molecules involved in phagocytic function, unlike the majority of the molecules involved in C3bi receptor function, are not freely diffusing in the monocyte membrane (Fig. 13). In this respect these molecules would be similar to the $\mathrm{C} 3$ receptors of resting mouse peritoneal macrophages, which also do not diffuse in the plane of the membrane (39). This explanation would be consistent with both the different dose-response curves for the fluid-phase Mo-1 and M1/70 effects on complement and IgG mediated functions, and with the apparent lack of effect of solid-phase $F\left(a b^{\prime}\right)_{2}$ on IgG Fc receptor function. Thus, comparison of inhibition of rosetting and phagocytosis by fluid-phase and solid-phase anti-Mac-1 antibodies suggests that there are two functionally distinct membrane molecules which express the Mac-1 antigen. The molecules involved in C3bi rosetting but not IgG phagocytosis diffuse in the membrane and may be trapped by solid phase antibodies; the molecules involved in phagocytosis do not diffuse and so are not trapped. This does not imply that the nondiffusing molecules possessing Mac-1 antigen cannot recognize $\mathrm{C} 3 \mathrm{bi}$; indeed the residual EC3bi rosetting observed by ourselves and others (3) to cells plated on solid-phase antibodies to CR3 may arise from these non-diffusing Mac-1 molecules.

Diffusing and nondiffusing pools have been demonstrated for several membrane antigens. For example $20-50 \%$ of surface immunoglobulins (40), vesicular stomatitis virus $G$ proteins, and IgE receptors are nondiffusing proteins, as determined by fluorescence photobleaching recovery (41). Only $60-70 \%$ of the mouse macrophage $\mathrm{Fc}$ receptor freely diffuses in the plane of the cell membrane, as determined by a technique similar to that used in this paper (42). However, our work represents the first demonstration of a biological function restricted to the nondiffusing subset of a membrane antigen. If enhancement of receptor aggregation in general is a property of the nondiffusing Mac-1 molecules, the in vitro abnormalities of Mac-1-deficient cells, as well as many of the clinical manifestations of Mac-1 deficiency, may result quite specifically from the loss of this form of the membrane molecule. This would suggest that the intramembranous and transmembrane association of this molecule will be of particular biological interest.

\section{Acknowledgments}

We would like to thank Dr. R. F. Todd III for the generous gift of IgG Mo-1 ascites and Dr. Phil Stahl for his critique of this manuscript.

This work was supported by grant R01-GM38330 from the National Institutes of Health.

\section{References}

1. Ault, K. A., and T. A. Springer. 1981. Cross-reacting a rat-antimouse phagocyte-specific monoclonal antibody (anti-Mac-1) with human monocytes and natural killer cells. J. Immunol. 126:359-364.

2. Springer, T., G. Galfre, D. S. Secher, and C. Milstein. 1979. Mac-1: a macrophage differentiation antigen identified by monoclonal antibody. Eur. J. Immunol. 9:301-306.
3. Wright, S. D., P. E. Rao, W. C. van Voorhis, L S. Craigmyle, K. Iida, M. A. Talle, E. F. Westberg, G. Goldstein, and S. C. Silverstein. 1983. Identification of the C3bi receptor of human monocytes and macrophages by using monoclonal antibodies. Proc. Natl. Acad. Sci. USA. 80:5699-5703.

4. Arnaout, M. A., R. F. Todd III, N. Dana, J. Melamed, S. F. Schlossman, and H. R. Colten. 1983. Inhibition of phagocytosis of complement $\mathrm{C} 3$ - or immunoglobulin $\mathrm{G}$ coated particles and of $\mathrm{C} 3 \mathrm{bi}$ binding by monoclonal antibodies to a monocyte-granulocyte membrane glycoprotein (Mol). J. Clin. Invest. 72:171-179.

5. Pommier, C. G., J. O'Shea, T. Chused, T. Takahashi, M. Ochoa, T. B. Nutman, C. Bianco, and E. J. Brown. 1984. Differentiation stimuli induce receptors for plasma fibronectin on the human myelomonocytic cell line HL-60. Blood. 64:858-866.

6. Ezekowitz, R. A. B., R. B. Sim, M. Hill, and S. Gordon. 1984. Local opsonization by secreted macrophage complement components: role of receptors for complement in uptake of Zymosan. J. Exp. Med. 159:244-260.

7. Ross, G. D., J. A. Cain, and P. J. Lachmann. 1985. Membrane complement receptor type three (CR3) has lectin-like properties analagous to bovine conglutinin and functions as a receptor for zymosan and rabbit eythrocytes as well as a receptor for iC 3b. J. Immunol. 134:3307-3315.

8. Madsen, L. H., and L. S. Rodkey. 1976. A method for preparing IgG $\mathrm{F}\left(\mathrm{ab}^{\prime}\right)_{2}$ fragments using small amounts of serum. J. Immunol. Methods 9:355-360.

9. Maizel, J. V. 1971. Polyacrylamide gel electrophoresis of viral proteins. Methods Virol. 5:179-246.

10. Towbin, H., T. Staehelin, and J. Gordon. 1979. Electrophoretic transfer of proteins from polyacrylamide gels to nitrocellulose sheets: procedure and some applications. Proc. Natl. Acad. Sci. USA. 76:4350-4354.

11. Todd, R. F. III, L. M. Nadler, and S. F. Schlossman. 1981. Antigens on human monocytes identified by monoclonal antibodies. J. Immunol. 126:1435-1442.

12. Steinbuck, M., and R. Audran. 1969. The isolation of IgG from mammalian sera with the aid of caprylic acid. Arch. Biochem. Biophys. 134:279-284.

13. Parham, P. 1983. On the fragmentation of monoclonal IgG1, IgG2a and IgG2b from Balb/c mice. J. Immunol. 131:2895-2902.

14. Bohnsack, J. F., J. J. O'Shea, T. Takahashi, and E. J. Brown. 1985. Fibronectin-enhanced phagocytosis of an alternative pathway activator by human culture-derived macrophages is mediated by the C4b/C3b complement receptor (CR1). J. Immunol. 135:2680-2686.

15. Pommier, C. G., S. Inada, L. Fries, T. Takahashi, M. M. Frank, and E. J. Brown. 1983. Plasma fibronectin enhances phagocytosis of opsonized particles by human peripheral blood monocytes. J. Exp. Med. 157:1844-1854.

16. Bohnsack, J. F., H. K. Kleinman. T. Takahashi, J. J. O’Shea, E. J. Brown. 1985. Connective tissue proteins and phagocytic cell function laminin enhances complement and $\mathrm{Fc}$ mediated phagocytosis by cultured human macrophages. J. Exp. Med. 161:912-923.

17. Michl, J., M. M. Pieczonka, J. C. Unkeless, and S. C. Silverstein. 1979. Effects of immobilized immune complexes on Fc- and complement-receptor function in resident and thioglycollate-elicited mouse peritoneal macrophages. J. Exp. Med. 150:607-621.

18. Ross, G. D., S. L. Newman, J. D. Lambris, J. Deverg-Pocius, J. A. Cain, and P. J. Lachmann. 1983. Generation of three different fragments of bound C 3 with purified factor I or serum II. Location of binding sites in the $\mathrm{C} 3$ fragments for factors $\mathrm{B}$ and $\mathrm{H}$, complement receptors, and bovine conglutinin. J. Exp. Med. 158:334-352.

19. O'Shea, J. J., E. J. Brown, B. E. Seligmann, J. A. Metcalf, M. M. Frank, and J. I. Gallin. 1985. Evidence for distinct intracellular pools of receptors for $\mathrm{C} 3 \mathrm{~b}$ and $\mathrm{C} 3 \mathrm{bi}$ in human neutrophils. J. Immunol. 134:2580-87.

20. Kurlander, R. J., and J. Batker. 1982. The binding of human immunoglobulin G1 monomer and small covalently crosslinked poly- 
mers of immunoglobulin G1 to human peripheral blood monocytes and polymorphonuclear leukocytes. J. Clin. Invest. 69:1-12.

21. Brown, E. J., and J. Bekisz. 1984. Neoantigens appear in human IgG upon antigen binding: detection by antibodies that react specifically with antigen-bound IgG. J. Immunol. 132:1346-1352.

22. Michl, J., M. M. Pieczonka, J. C. Unkeless, G. I. Bell, and S. C. Silverstein. 1983. Fc receptor modulation in mononuclear phagocytes maintained on immobilized immune complexes occurs by diffusion of the receptor molecule. J. Exp. Med. 157:2121-2139.

23. Beller, D. I., T. A. Springer, and R. D. Schreiber. 1982. AntiMac-1 selectivity inhibits the mouse and human type three complement receptor. J. Exp. Med. 156:1000-1009.

24. Ross, G. D., J. A. Cain and P. J. Lachmann. 1985. Membrane complement receptor type 3 has lectin-like properties analagous to bovine conglutinin and functions as a receptor for zymosan and rabbit erythrocytes as well as a receptor for iC 3b. J. Immunol. 134:33073315.

25. Kurlander, R. J. 1983. Blockade of Fc receptor-mediated binding to $\mathrm{U} 937$ cells by murine monoclonal antibodies directed against a variety of surface antigens. J. Immunol. 131:140-147.

26. Sanchez-Madrid, F., J. A. Nagy, E. Robbins, P. Simon, and T. A. Springer. 1983. A human leukocyte differentiation antigen family with distinct subunits and a common subunit: the lymphocyte function-associated antigen (LFA-1), the C3bi complement receptor (OKMI/Mac-1), and the p 150, 95 molecule. J. Exp. Med. 158:17851803.

27. Looney, R. J., G. N. Abraham, and C. L. Anderson. 1986. Human monocytes and U937 cells bear two distinct Fc receptors for IgG. J. Immunol. 136:1641-1647.

28. Anderson, C. L. 1982. Isolation of the receptor for IgG from a human monocyte cell line (U937) and from human peripheral blood monocytes. J. Exp. Med. 156:1794-1799.

29. Kurlander, R. J. 1980. Reversible and irreversible loss of Fc receptor function of human monocytes as a consequence of interaction with immunoglobulin G. J. Clin. Invest. 66:773-781.

30. Leslie, R. G. Q. 1980. Macrophage handling of soluble immune complexes. Ingestion and digestion of surface-bound complexes at 4,20 and $37^{\circ} \mathrm{C}$. Eur. J. Immunol. 10:323-333.

31. White, C. E., and R. J. Argauer. 1970. Fluorescence Analysis: a Practical Approach. Marcel Dekker, Inc., New York. 104.
32. Sung, S.-S. J., R. S. Nelson, and S. C. Silverstein. 1985. Mouse peritoneal macrophages plated on mannan- and horseradish peroxidase-coated substrates lose the ability to phagocytose, by their Fc receptors. J. Immunol. 134:3712-3717.

33. Wright, S. D., and S. C. Silverstein. 1984. Phagocytosing macrophages exclude proteins from the zones of contact with opsonized targets. Nature (Lond.) 309:359-361.

34. Carter, S. D., R. G. Q. Leslie, and W. G. Reeves. 1982. Human monocyte binding of homologous monomer and complexed IgG. Immunology. 46:793-800.

35. Steplewski, Z., M. D. Lubeck, and H. Koprowski. 1983. Human macrophages armed with murine immunoglobulin G2a antibodies to tumors destroy human cancer cells. Science (Wash. DC) 221:865-867.

36. Dana, N., B. Styrt, J. D. Griffin, R. F. Todd III, M. S. Klempner, and M. A. Arnaout. Two functional domains in the phagocyte membrane glycoprotein Mo-1 identified with monoclonal antibodies. J. Immunol. 137:3259-3263.

37. Mellman, I., H. Plutner, and P. Ukkonen. 1984. Internalization and rapid recycling of macrophage Fc receptors tagged with monovalent antireceptor antibody: possible role of a prelysosomal compartment. J Cell Biol. 98:1163-1169.

38. Nauseef, W. M., P. de Alarcon, J. F. Bale, and R. A. Clark. 1986. Aberrant activation and regulation of the oxidative burst in neutrophils with Mo-1 glycoprotein deficiency. J. Immunol. 137:636642.

39. Kaplan, G., T. Eskeland, and R. Selgelid. 1978. Differences in the effect of immobilized ligands on the $\mathrm{Fc}$ and $\mathrm{C} 3$ receptors of mouse peritoneal macrophages in vitro. Scand. J. Immunol. 7:19-32.

40. Henis, Y. I., and E. L. Elson. 1981. Inhibition of the mobility of mouse lymphocyte surface immunoglobulins by locally bound concanavalin A. Proc. Natl. Acad. Sci. USA. 78:1072-1076.

41. Peters, R. 1981. Translational diffusion in the plasma membrane of single cells as studied by fluorescence microphotolysis. Cell Biol. Int. Rep. 5:733-761.

42. Michl, J., J. C. Unkeless, M. M. Pieczonka, and S. C. Silverstein. 1983. Modulation of Fc receptors of mononuclear phagocytes by immobilized antigen-antibody complexes: quantitation analysis of the relationship between ligand number and Fc receptor response. J. Exp. Med. 157:1746-1757. 